\title{
The Duke neurology advanced practice provider residency: Its time has come
}

Nitin K. Sethi, MD: I read with interest Morgenlander and Blessing's ${ }^{1}$ experience with developing a 1-year neurology residency program for advanced practice providers (APPs), namely nurse practitioners (NPs) and physician assistants (PAs), in their institution. While I laud the authors in their effort and believe that APPs with formal training in neurology shall improve patient care, I disagree this is the way forward to address the growing shortage of neurologists. An APP with additional training in neurology is still an APP unable to independently diagnose and treat complex neurologic disorders with confidence. While APPs with additional training in neurology are a useful addition to the neurology workforce, they should not be a substitute for additional residency-trained neurologists. Congress needs to act now to alleviate this shortage. That should be the message we send out.

New York-Presbyterian Hospital.

Disclosures: N. Sethi serves as Associate Editor of The Eastern Journal of Neurology.

Authors Respond: Joel C. Morgenlander, MD; Robert Blessing, ACNP, DNP: We appreciate the comments by Dr. Sethi in response to our article about our APP Neurology residency. ${ }^{1}$ Training APPs in neurology is one way to improve the manpower issues facing our specialty. This does not suggest that increasing the numbers of trained neurologists is not important, although the Neurology Match numbers would suggest the issue is in our recruitment of neurologists, as our Match did not fill. While we agree that Congress should act to improve the access to neurologic care, funding of the APP Neurology residencies as well as other specialty APP programs would be a wise contribution to improving medical access. If funding for these types of programs improved, we would see substantial numbers of APP providers obtain more specialized training. We believe many of our Neurology APPs would be capable of seeing new patients as well as returns, although they would have staff backup if needed.

Duke University Medical Center, Durham, NC.

Disclosures: J.C. Morgenlander has served as a consultant to the National Football League, receives research support from Biogen Idec, and holds stock/stock options in Zinfandel Pharmaceuticals, Inc. R. Blessing reports no disclosures.

1. Morgenlander JC, Blessing R. The Duke neurology advanced practice provider residency. Neurol Clin Pract 2016;6:277-280.

\section{What's New in Clinical Practice?}

Neurology ${ }^{\circledR}$ Clinical Practice now has podcasts available for download. The podcasts are introduced by Editor John R. Corboy, MD, FAAN, who highlights papers from the current issue. The interview that follows features authors discussing papers in more depth and bringing clinical implications to the fore. 


\section{Neurology ${ }^{\circ}$ Clinical Practice}

The Duke neurology advanced practice provider residency: Its time has come

Nitin K. Sethi, Joel C. Morgenlander and Robert Blessing

Neurol Clin Pract 2016;6;378

DOI 10.1212/CPJ.0000000000000302

This information is current as of October 17, 2016

\begin{tabular}{|c|c|}
\hline $\begin{array}{l}\text { Updated Information \& } \\
\text { Services }\end{array}$ & $\begin{array}{l}\text { including high resolution figures, can be found at: } \\
\text { http://cp.neurology.org/content/6/5/378.full.html }\end{array}$ \\
\hline References & $\begin{array}{l}\text { This article cites } 1 \text { articles, } 1 \text { of which you can access for free at: } \\
\text { http://cp.neurology.org/content/6/5/378.full.html\#\#ref-list-1 }\end{array}$ \\
\hline Permissions \& Licensing & $\begin{array}{l}\text { Information about reproducing this article in parts (figures,tables) or in } \\
\text { its entirety can be found online at: } \\
\text { http://cp.neurology.org/misc/about.xhtml\#permissions }\end{array}$ \\
\hline Reprints & $\begin{array}{l}\text { Information about ordering reprints can be found online: } \\
\text { http://cp.neurology.org/misc/addir.xhtml\#reprintsus }\end{array}$ \\
\hline
\end{tabular}

Neurol Clin Pract is an official journal of the American Academy of Neurology. Published continuously since 2011, it is now a bimonthly with 6 issues per year. Copyright () 2016 American Academy of Neurology. All rights reserved. Print ISSN: 2163-0402. Online ISSN: 2163-0933.

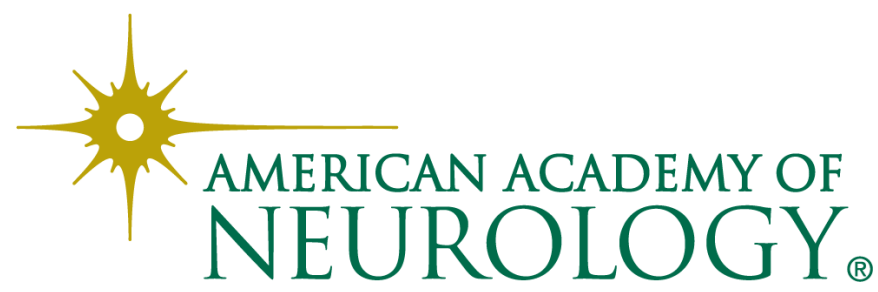

